\title{
EVALUATION OF PERFORMANCE PROPERTIES OF TWO COMBUSTOR TURBOFAN ENGINE
}

\section{OCENA WŁAŚCIWOŚCI EKSPLOATACYJNYCHDWUPRZEPŁYWOWEGO SILNIKA TURBINOWEGO Z DWIEMA KOMORAMI SPALANIA}

\begin{abstract}
This article presents issues connected with modification of a bypass engine with an additional combustion chamber placed between the high pressure and low pressure turbines. At the beginning, on the basis of scientific literature analysis possible benefits were pointed out which follow from modification of a turbofan aircraft engine. First of all, the attention was drawn to a possibility to limit the gas temperature in the exhaust area of a combustion chamber, which helps to reduce NOx in relation to currently used aircraft engines. Then, a design solution scheme of a two combustor engine was presented. It was discussed how this solution modifies the engine cycle. The assumptions and the adopted limitations in the stage of preparing a numerical model of the engine were presented. The main parameters of the engine operating which were used to estimate its functional qualities were characterized. On the bases of an existing high bypass ratio turbofan engine and the assumptions concerning the influence of the mentioned modification of the engine to its internal characteristics performance properties of a two combustor engine in variable performance conditions were determined: for different speeds and flight altitudes. The results were graphically illustrated in the charts in the form of dependences of thrust, specific thrust, fuel consumption and specific fuel consumption vs. the flight speed for different altitudes. In the discussion of the obtained results performance characteristics for standard a high bypass ratio turbofan engine were referred to. On this basis possible benefits which follow from exploitation of the two combustor engine were shown. This engine is characterized by better performance characteristics in comparison to a conventional turbofan engine in the range of transonic velocity. It was pointed out that despite a little higher specific fuel consumption in take-off conditions it can be more economic in further exploitation cycle, which in the case of the aircraft for which it is dedicated, takes place mostly at a transonic velocity at the altitude of about $11 \mathrm{~km}$.
\end{abstract}

Keywords: aircraft engine, turbofan engine, modifications and development of a turbofan engine, characteristics of turbofan engine.

$W$ artykule przedstawiono zagadnienia zwiazane z modyfikacja silnika dwuprzepływowego o dodatkowa komore spalania usytuowana pomiędzy turbina wysokiego i niskiego ciśnienia. Na wstępie, na podstawie analizy literatury, wskazano możliwe korzyści wynikające z zastosowania takiej modyfikacji lotniczego silnika dwuprzeptywowego. Przede wszystkim zwrócono uwage na możliwość ograniczenia maksymalnej temperatury spalin w przekroju wylotowym komory spalania w silniku tego typu, przez co istnieje możliwość istotnej redukcji NOx w odniesieniu do współcześnie eksploatowanych silników lotniczych. Następnie przedstawiono schemat rozwiazania konstrukcyjnego silnika z dwiema komorami spalania. Omówiono, jak takie rozwiazanie modyfikuje obieg silnika. Przedstawiono założenia i przyjęte ograniczenia na etapie przygotowywania modelu numerycznego silnika oraz scharakteryzowano główne parametry pracy silnika, które wykorzystano do oceny jego właściwości eksploatacyjnych. Na bazie danych istniejącego silnika dwuprzeptywowego o dużym stopniu dwuprzeptywowości oraz przyjętych zatożeń odnośnie wplywu omawianej modyfikacji silnika na jego charakterystyki wewnętrzne, wyznaczono osiagi silnika z dwiema komorami spalania $w$ zmieniających się warunkach eksploatacji tj. dla różnej prędkości i wysokości lotu. Wyniki zilustrowano graficznie na wykresach w postaci zależności ciagu, ciagu jednostkowego, zużycia paliwa i jednostkowego zużycia paliwa od prędkości lotu dla różnych wysokości. W dyskusji uzyskanych wyników odniesiono się do charakterystyk eksploatacyjnych dla standardowych silników dwuprzepływowych o dużym stopniu dwuprzeptywowości. Na tej podstawie wykazano możliwe korzyści wynikające z eksploatacji silnika z dwiema komorami spalania. Silnik ten cechuje korzystniejszy przebieg charakterystyk eksploatacyjnych od klasycznego silnika dwuprzeptywowego w zakresie prędkości okołodźwiękowych. Zaznaczono, że pomimo nieco wyższych wartości jednostkowego zużycia paliwa w warunkach startowych, może on być ekonomiczniejszy w całym cyklu eksploatacyjnym, który w przypadku statków powietrznych do których jest dedykowany, odbywa się w zdecydowanej większości czasu z prędkościa okołodźwiękowa na wysokości ok $11 \mathrm{~km}$.

Stowa kluczowe: silnik turbinowy, silnik dwuprzepływowy, modyfikacje i rozwój silnika turbinowego, charakterystyki silnika turbinowego.

\section{Introduction}

In air-transport two or three shafts high bypass ratio turbofan engines and turboprop engines are the dominant kind of propulsion. Both of the types found their use in aircrafts because of their profitable performance characteristics. First of all, this is low specific fuel consumption, which is about $20 \%$ of the value of this parameter for turbojet engines [15, 18].

Turboprop engines are characterized by a lower specific fuel consumption than high bypass turbofan engines. However, a significant limitation of these engines is a lower cruise speed which follows from limitations connected with a significant decrease of propellers per-

(*) Tekst artykułu w polskiej wersji językowej dostępny w elektronicznym wydaniu kwartalnika na stronie www.ein.org.pl 
formance when flight speed closes to transonic velocities. Moreover, these propulsion systems make more noise, that is why they are more burdensome for the environment $[3,17]$.

At present, high bypass turbofan engines are the best solution for long range passenger and transport aircrafts. That is why, further steps have been undertaken by engine manufacturers in order to improve performance properties of these propulsions. Challenges which are put forward are as follows: to decrease fuel consumption, to decrease environmental pollution and noise at maintaining the highest level of reliability in a long-term exploitation [15]. For this reason, the scientists who deal with aircraft engines undertook this research topic.

One of the areas of activities is to find a method of selection of a power unit to an aircraft taking into consideration flying tasks performed by the aircraft. In this respect, works use the methods of optimization and multicriteria optimization in order to determine solutions of the propulsion unit which best meets tactical and technical requirements as for designed aircraft [13, 21, 22].

Another area of research covers the issue of improvement and development of turbofan engines design. The works which deal with this area include: determination of methods of reduction of fuel consumption and emission of pollution to the environment, identification of sources of noise in the engine and possibilities of its limitation, strength tests of selected elements of the engine and whole units in dynamic states, as well as modern materials and manufacturing technologies used in aircraft industry $[3,14,16,19,20]$.

The research on modification of the cycle of a turbofan engine in order to increase its properties has been carried out for several years. It covers the analysis and energy estimation of the operating cycle of the engine obtained as a result of modifications of the processes taking place in it. Currently, the main streams of modifications of the engine cycle concern additional interstage turbine burning [12, 17], or burning in the additional combustor situated between the high and low pressure turbines in a two-spool engine $[5,7,9,10]$. The results of these works show that such a solution should be more beneficial from the point of view of energy because in a certain part the heating process should be similar to isothermal process which occurs in the cycle of the highest performance - the Carnot cycle [17]. From the ecological point of view, it is shown that practical implementation of the suggested solutions will enable obtainment of maximal temperature of the engine cycle at maintaining unchanged performance, which should have a beneficial influence of limitation of emission of nitrogen oxides [9, $10]$.

The engine with an additional combustion chamber between the turbines seems to be a variation which is likely to implement in the future (currently, there is an industrial gas turbine manufactured by $\mathrm{ABB})$. That is why a conception of a two combustor engine and the results of its performance characteristics will be considered. The reference point will be a high bypass turbofan engine on the basis of which simulation calculations of the modified engine will be carried out.

\section{A turbofan engine with an additional combustion chamber between the high and low pressure tur- bines}

High bypass turbofan engines are currently produced as two- or three-spool arrangement. In two-spool arrangement the fan and the low-pressure compressor are powered by the high pressure turbine. In three-spool arrangement the fan, the high pressure compressor and the low pressure compressor are powered by separate turbines. The combustion chamber is placed between the high pressure compressor and the high pressure turbine. Energy of the exhaust gases should be enough to power the turbines and to produce the thrust, that is why the temperature of the gases which leave the combustor should be relatively high. Currently, it is about $1700-1800 \mathrm{~K}$, which causes that the turbines have to be made of appropriate materials and additionally should be equipped with an advanced cooling system of disks and blades $[2,4,8,16,18]$. The cooling system makes the design of the engine more difficult and causes that a large part of the compressed air should be used to cool the turbine's blades, that is why it does not take an active part in producing power in the turbine [2, 4]. As a result, the decrease of temperature and pressure in the turbine is greater in comparison to the work of the engine with similar operating parameters in the case when the turbine does not require cooling. As a result, as it is mentioned in work [2], there is a decrease of the engine's performance.

\section{5' External nozzle} $\longrightarrow$ Zewnętrzna dysza wylotowa b 3 b 3 3a 3 3b 4 Wewnętrzna dysza wylotowa

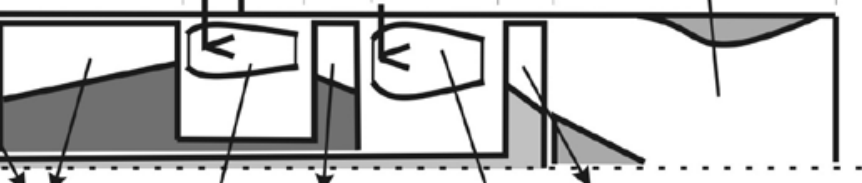

ompressors/ Sprężarki Sprez ki

Turbina WC Additional combustor/

$\begin{array}{ll}\text { Combustor/ } & \text { Dodatkowa komora spalania } \\ \text { Komora spalania }\end{array}$

a turbofan engine with an additional combustion chamber between the turbines

The analysis of operation of a two-spool turbofan engine with an additional combustion chamber between the turbines, which scheme is shown in Figure 1, is presented. The additional combustor is placed between the high pressure turbine and the low pressure turbine, due to additional gas heating. It allows limiting the amount of heat added to the main combustor. It was assumed that the temperature of the exhaust gases going out of both combustors would be up to $1300 \mathrm{~K}$. Such a solution allows eliminating the use of advanced systems to cool the turbines, including the internal cooling of the disks and the blades. It also significantly limits the amount of air bleeding of the engine's compressor for cooling purposes [2, 18]. Additional benefits which follow from such a solution are: decreasing the level of complicacy of the design of the disks and blades of the turbine (they are made without internal holes to transport the cooling air), that is why it helps to reduce manufacturing costs and increase the time of reliable work of the unit [11].

\section{The analysis of the cycle and performance of the engine with an additional combustor between the turbines}

The scheme of the cycle of the engine with two combustors is presented in Figure 2. A significant modification in a description of a numerical model of the cycle is that the total heat added to the engine is a sum of heat added in the main and additional combustors, which is presented as:

$$
Q_{t}=Q_{B_{-} t}+Q_{I T_{-} t}
$$

where: $Q$ - heat added to the engine,

indexes: $t$ - for total parameters, $B$ - main combustor, $I T-$ additional combustor between the turbines (inter turbines). 


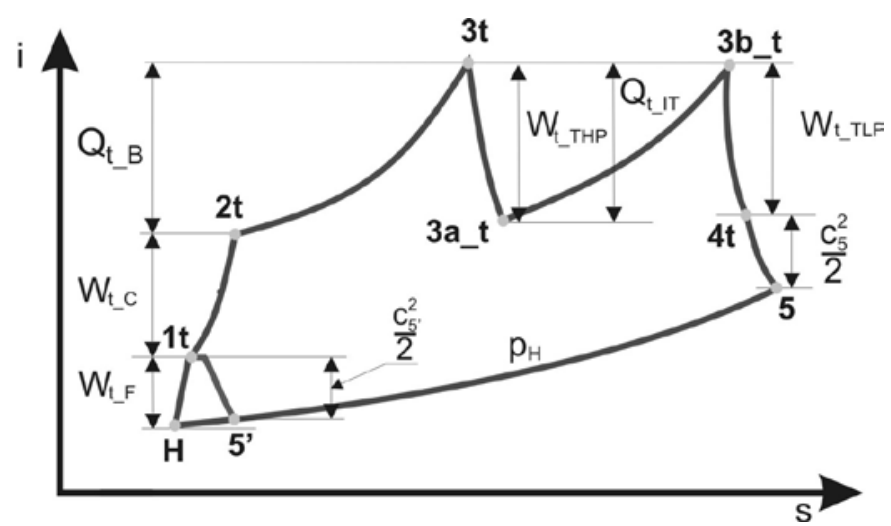

Fig. 2. Enthalpy-entropy diagram of the engine with two combustors, indications: $W_{t}-$ work, $Q_{t}-$ heat, $c$-gases flow velocity, $1,2 \ldots 5$ - indications of the engine's cross-section according to Fig. 1

The heat added in the main combustor is determined from the equation:

$$
Q_{B_{-} t}=\frac{m_{f_{-} B}}{m_{I}} h \eta_{B}=C_{p}\left(T_{3 t}-T_{2 t}\right)
$$

However, the heat added in an additional combustor is determined as:

$$
Q_{I T_{-} t}=\frac{m_{f_{-} I T}}{m_{I}} h \eta_{I T}=C_{p}\left(T_{3 b_{-} t}-T_{3 a_{-} t}\right)
$$

where:

$m_{f_{-} B}, m_{f_{-} I T}-$ mass flow of the fuel in the main and additional combustors,

$m_{I}$ - mass flow of the air in the entry to the core engine,

$h$ - caloric value of the fuel,

$\eta_{B}, \eta_{I T}-$ thermal efficiency of the combustor and the inter turbine burner,

$C_{p}$ - specific heat at constant pressure,

$T$ - temperature.

Total mass flow of the fuel in the engine is presented by the equation:

$$
\sum m_{f}=m_{f_{-} B}+m_{f_{-} I T}=\left(m_{I} Q_{t}\right) /\left(h\left(\eta_{B}+\eta_{I T}\right)\right)
$$

The engine's thrust is calculated as:

$$
F=m_{5} c_{5}+m_{I} \alpha c_{5^{\prime}}-m_{I}(1+\alpha) V
$$

Specific thrust:

$$
F_{S}=\left(\frac{m_{5}}{m_{I}} c_{5}+\alpha c_{5^{\prime}}-(1+\alpha) V\right) /(1+\alpha)
$$

where:

$$
\begin{aligned}
& F-\text { thrust, } \\
& F_{s}-\text { specific thrust, } \\
& m_{5}-\text { mass flow of the core engine exhaust gases at the outlet } \\
& \text { nozzle, }
\end{aligned}
$$

$c_{5}, c_{5}$, - gas velocity in the exhaust area of the internal and external nozzle,

$\alpha$ - bypass ratio,

$V$ - flight velocity.

Specific fuel consumption is determined from the equation:

$$
S_{f}=\sum m_{f} / F
$$

Specific fuel consumption and specific thrust are very important parameters which determine performance properties of an engine. Low specific fuel consumption is of special importance from the point of view of exploitation. This indicator determines the costs which are directly connected with the tasks performed by an aircraft. Low specific fuel consumption causes that less fuel is needed to perform a certain task, which reduces the flight costs, and, on the other hand, at a specified take-off mass of an aircraft it increases the possible commercial weight [13]. Lower fuel consumption also has an ecological aspect, because it causes a limitation of a quantity of exhaust products emitted to the environment [8].

\section{Determination of basic design parameters of a tur- bofan engine with an additional combustor}

The data for the GE90-85B turbofan engine were used to define basic design parameters of the engine [23]. This engine's bypass ratio is 8.1 , fan pressure ratio is 1.65 , low pressure compressor pressure ratio is 1.141 , and total pressure ratio of the engine is 40.4 .

It was stated in work [7] that the cycle of a two combustor turbofan engine can be optimized in order to meet both criteria: maximum specific thrust and minimum specific fuel consumption. That is why in the analyzed engine with an additional combustor it was assumed that the bypass ratio, the fan and the low pressure compressor pressure ratio are similar to the GE90-85B engine. However, the value of the total compression ratio was determined through optimization of the two combustor turbofan engine cycle regarding the criterion of maximum specific thrust and minimum specific fuel consumption.

The values of the internal engine processes coefficients were assumed on the basis of the data presented in work [23]. The value of coefficients used to describe the processes in the additional combustor were assumed on a lower level than for the main combustor. By this way the pressure loss coefficient is $96 \%$ (99\% for the main combustor), and the combustion efficiency is $96.5 \%$ (99\% for the main combustor). Such an assumption follows from the fact that in the additional combustor there would be worse conditions for the process due to a higher flow velocity and that instead of the air a mixture of exhausts and air inflow to the additional combustor.

In calculations of gas properties in the engine control sections a zero-dimensional model presented in works $[6,8,18]$ was used, which was adjusted to the requirements of calculations for the engine with two combustors according to the correlations presented in Part 3. In order to increase precision of the calculation a gas flowing though the engine was assumed as semi-perfect; its model was taken from work [1].

The value of total pressure ratio of the engine with an additional combustor on account of the cycle optimization was assumed to be 26.36 (the GE-90 engine's total pressure ratio is 40.4), which cases that the high pressure compressor pressure ratio is 14 at the assumed values of the compression ratio of the low pressure shaft.

For the selected parameters of the engine work the total temperature and pressure distribution in engine sections are presented in Figure 3 . The following performance parameters of the engine were determined: thrust and specific fuel consumption. In take-off conditions the engine's specific thrust is $286.2 \mathrm{Ns} / \mathrm{kg}$, specific fuel consumption 


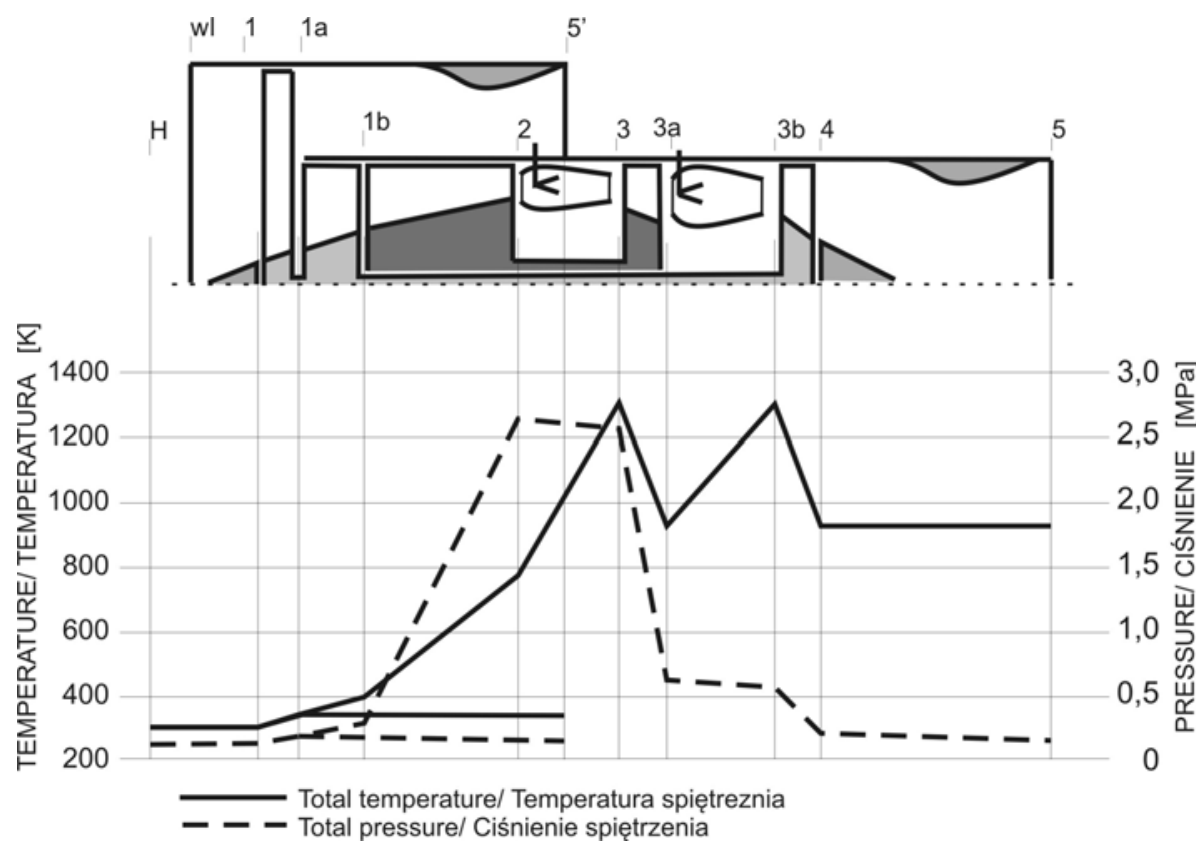

Fig. 3. Diagram of total temperature and pressure distribution in the engine control sections

Table 1. Comparison of basic parameters determined for the two combustor engine and data for the GE90-85B engine [23] for take-off condition

\begin{tabular}{||l|c|c||}
\hline & Two-combustor engine & GE90-85B engine \\
\hline Total pressure ratio & 26.4 & 40.4 \\
\hline Air mass flow $[\mathrm{kg} / \mathrm{s}]$ & 1350 & 1350 \\
\hline Thrust $[\mathrm{kN}]$ & 386.4 & 375.3 \\
\hline Specific thrust $[\mathrm{Ns} / \mathrm{kg}]$ & 286.2 & 278.1 \\
\hline Specific fuel consumption $[\mathrm{kg} / \mathrm{daN} / \mathrm{h}]$ & 0.344 & 0.285 \\
\hline Fuel consumption $[\mathrm{kg} / \mathrm{s}]$ & 3.69 & 2.99 \\
\hline
\end{tabular}

is $0.344 \mathrm{~kg} / \mathrm{daN} / \mathrm{h}$, thrust is $386.4 \mathrm{kN}$ and fuel consumption is 3.69 $\mathrm{kg} / \mathrm{s}$. Comparison of basic parameters of the engine with an additional combustor and the data for the GE90-85B engine are presented in Table 1.

The determined values show that the two-combustor engine has a similar thrust. However, it has a higher specific fuel consumption. This unfavorable effect can be caused by two reasons. Firstly, too low coefficients of the processes in the additional combustor were assumed. This has a significant influence on the increase of the specific fuel consumption, which can be deducted on the basis of the research presented in work [6]. Secondly, the increase of the turbine performance due to elimination of cooling processes was not taken into account. These issues will be analyzed in the next scientific research.

\section{Flight performance of a two-combustor engine}

A numeric model of an engine was developed in the Matlab environment. It was done in order to determine the influence of flight conditions on a two combustor turbofan engine performance which follow from the area of exploitation of aircraft engines. The parameters which determine performance properties of the engine were defined earlier and they were: thrust, specific thrust, fuel consumption and specific fuel consumption. Changes of the ambient parameters with the altitude were regarded according to the ISA (International Standard Atmosphere) model.

At the stage of developing the model for variable conditions of the flight it was assumed that the pressure ratio of the fan and compres- sors and expansion of the turbines would not change. It is correct when the engine's operation for constant point of characteristics expressed by corrected parameters. It follows from this assumption that:

- corrected mass flow of the air in the fan and the compressor is constant, i.e. a condition for the fan is fulfilled:

$$
m \frac{\sqrt{T_{H t}\left(M_{a}, H\right)}}{p_{H t}\left(M_{a}, H\right)}=m_{o b l}\left(\frac{\sqrt{288}}{101325}\right)
$$

a condition for the high pressure compressor is fulfilled:

$$
m_{I} \frac{\sqrt{T_{1 a t}\left(M_{a}, H\right)}}{p_{1 a t}\left(M_{a}, H\right)}=m_{I_{-} o b l}\left(\frac{\sqrt{T_{1 a t \_o b l}}}{p_{1 a t_{-} o b l}}\right)
$$

- corrected rotation speed of the low and high pressure rotors are constant, i.e.

$$
\begin{aligned}
& \frac{n_{N C}\left(M_{a}, H\right)}{\sqrt{T_{H t}\left(M_{a}, H\right)}}=\text { const } \\
& \frac{n_{W C}\left(M_{a}, H\right)}{\sqrt{T_{1 b t}\left(M_{a}, H\right)}}=\text { const }
\end{aligned}
$$

turbomachinery efficiencies do not change.

On the basis of the assumptions, the mass flow of the inlet air into the engine in the function of velocity and flight altitude was determined from the equation (8), and the mass flow of the air inlet into the core engine was determined from the equation (9). The equations (10) and (11) were used to estimate real rotors speed, and then to determine the temperature value of the gases in the inlet section of the high and low pressure turbines. In order to do it a criterion of constant corrected rotation speed of the high pressure turbine rotor was used:

$$
\frac{n_{W C}\left(M_{a}, H\right)}{\sqrt{T_{3 t}\left(M_{a}, H\right)}}=\text { const }
$$

Alike for the rotor of the low pressure turbine:

$$
\frac{n_{N C}\left(M_{a}, H\right)}{\sqrt{T_{3 b t}\left(M_{a}, H\right)}}=\text { const }
$$

Equality of the real rotation speed of the compressor or the fan and the turbine on the same spool should be fulfilled. From the combination of equation (10) and (13) as well as (11) and (12) dependences for the temperature of the exhaust gases from the main combustor were related as:

$$
T_{3 t}\left(M_{a}, H\right)=T_{3 t \_o b l} \frac{T_{1 b t}\left(M_{a}, H\right)}{T_{1 b t \_o b l}}
$$


and the temperature of the exhaust gases from the additional combustor were related as:

$$
T_{3 b t}\left(M_{a}, H\right)=T_{3 b t_{-} o b l} \frac{T_{H t}\left(M_{a}, H\right)}{288}
$$

where:

$T_{3 t}\left(M_{a}, H\right)$ - total temperature of gas at the combustor's outlet for different flight speeds $\mathrm{Ma}$ and altitude $\mathrm{H}$,

$T_{3 b t}\left(M_{a}, H\right)$ - total temperature of gas at the additional combustor's outlet for different flight speeds Ma and altitude H,

$T_{3 b t ~ o b l}$ - total temperature of gases at the combustor's outlet in design conditions

$T_{H t}\left(M_{a}, H\right)$ - total temperature of gas in the inlet to the engine which is determined from the equation:

$$
T_{H t}\left(M_{a}, H\right)=T_{H}(H)\left(1+\frac{k-1}{2} M_{a}^{2}\right)
$$

On the basis of the presented assumptions and the developed numerical model performance of the two combustor turbofan engine versus flight speed and altitude were determined. Some of them are presented in Figure 4.
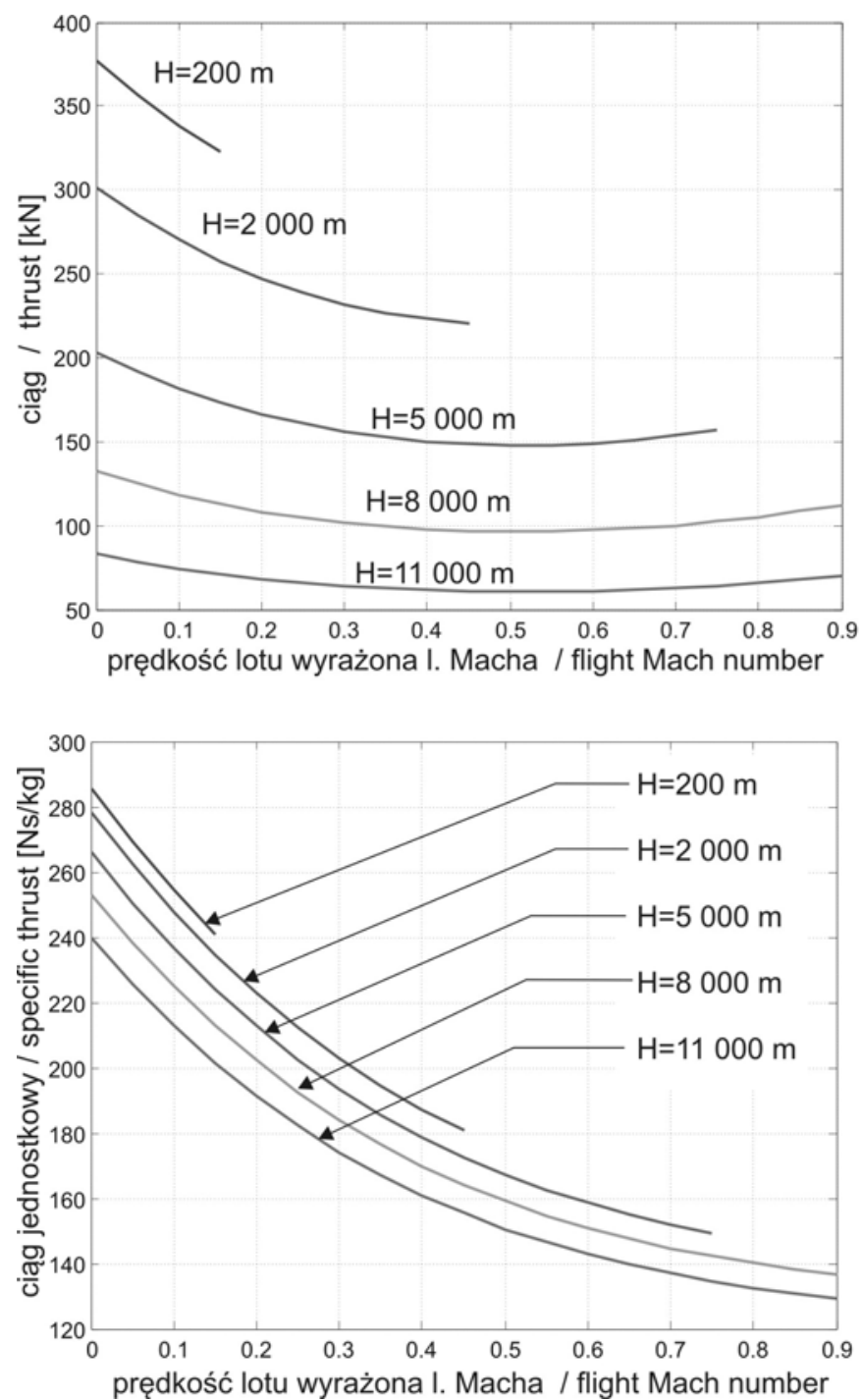

The presented results of the simulation of the engine's operation were aborted because for the given altitude further increase of the flight speed caused the necessity to exceed permissible gas turbine inlet temperature. The program of controlling the engine should guarantee maintenance of a constant temperature in its further operating range, however, the assumptions accepted at the level of development of the model do not allow continuation of reliable calculations for these conditions of the engine's operation. Characteristics of gases temperature in the outlet section of the main combustor in the function of flight speed and altitude were presented in Figure 5. For the additional combustor the temperature diagram in the outlet section is similar.

On the basis of the determined values of the thrust in the function of the flight altitude it is possible to state that for bigger altitude levels, when the speed reaches about $0.5 \mathrm{Ma}$, the engine thrust after initial decrease starts increasing. This differentiates the two combustor turbofan engine from a conventional turbofan where thrust characteristics in a whole speed range decrease [18].

It is also reflected in the specific fuel consumption vs. altitude and flight speed performance which for a conventional high bypass turbofan engine is much different when the speed gets close to the speed of sound. In a two combustor engine due to the increase of thrust at higher speeds, specific fuel consumption increases slower. This shows that the performance of a two combustor turbofan engine in flight
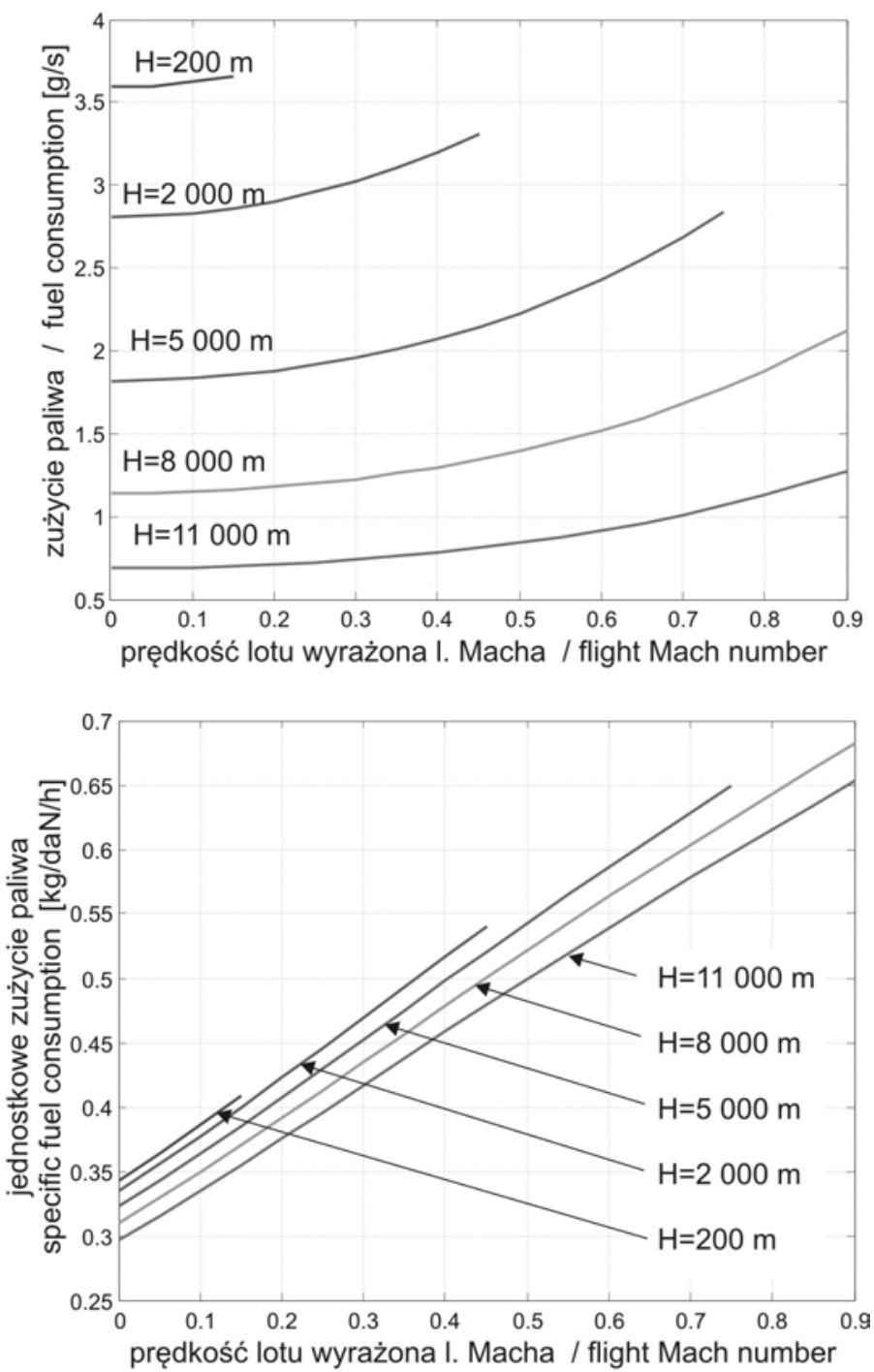

Fig. 4. Dependence of selected performance characteristics of a two combustor turbofan engine for different flight speeds and altitude (H - altitude) 


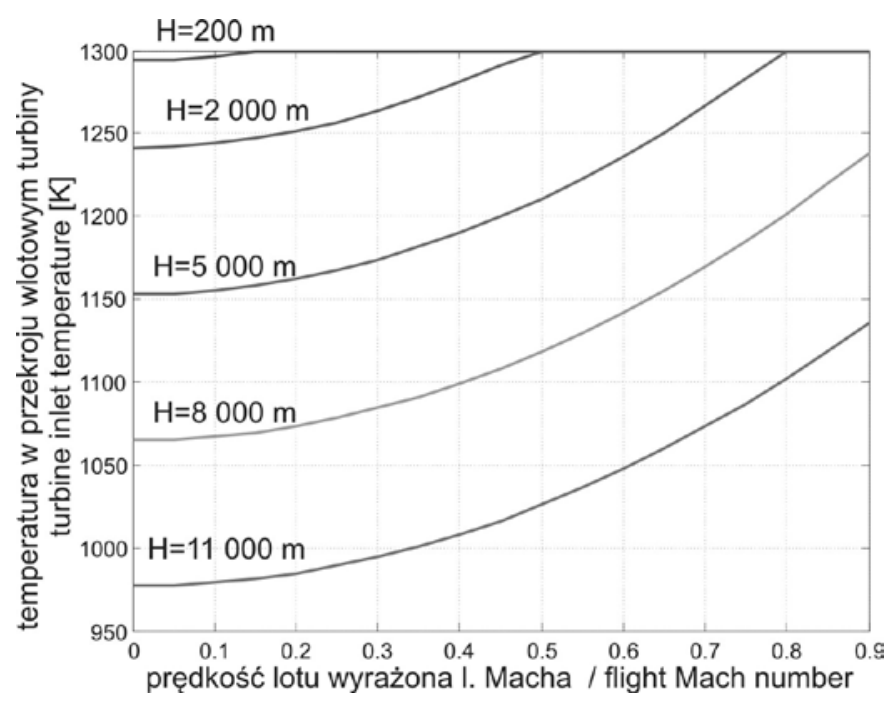

Fig. 5. Gas turbine inlet temperature of a two combustor turbofan engine vs. flight speeds and altitude ( $H$ - altitude)

range operating conditions (altitude about $11 \mathrm{~km}$, speed about $0,8 \mathrm{Ma}$ ) should be more beneficial than those of a conventional turbofan.

\section{Summary and conclusions}

The presented analysis showed that the two combustor engine can be an interesting solution of modification of a conventional turbofan engine for airliners. It requires a use of an additional combustor placed between the high and low pressure turbines. However, due to this solution it would be possible to decrease maximal temperature of gases in the high pressure turbine inlet. As a result of this it should be done an increase of reliability and life time of core engine structures, simplification of manufacturing technology of the turbines and reduction of NOx emission.

The results show that the two combustor engine has a smaller value of a total pressure ratio (a smaller compressor) in order to produce the same take-off thrust at the same air flow than conventional turbofan. A smaller pressure ratio causes an increase of a specific fuel consumption in take-off conditions. However, in the range of the flight with high speeds the performance of a two combustor engine are more beneficial that those of a conventional turbofan engine. It shows that this engine can be characterized by lower specific fuel consumption in cruise conditions at speeds close to those at which modern transport and passenger aircrafts fly.

\section{References}

1. Guha A. An efficient generic method for calculating the properties of combustion products. Proceedings of the Institution of Mechanical Engineers 2001; A3(215): 375-387, http://dx.doi.org/10.1243/0957650011538596.

2. Horlock J H, Watson D T, Jones T V. Limitations on Gas Turbine Performance Imposed by Large Turbine Cooling Flow. Journal of Engineering for Gas Turbines and Power 2001; 123: 487-494, http://dx.doi.org/10.1115/1.1373398.

3. Huff D L. NASA Glenn's Contributions to Aircraft Engine Noise Research. Journal of Aerospace Engineering 2013; 2(26): 218-250, http:// dx.doi.org/10.1061/(ASCE)AS.1943-5525.0000283.

4. Jakubowski R. Modeling and analysis of jet engine with cooling turbine. Journal of KONES Powertrain and Transport 2012; 2(19): 235-243.

5. Jakubowski R. Two-Combustor Turbofan engine Performance Analysis. Journal of KONES Powertrain and Transport 2014; 3(21): 141-148, http://dx.doi.org/10.5604/12314005.1133191.

6. Jakubowski R, Orkisz M. Wpływ zmian procesów przepływowo-cieplnych w silniku turbinowym na jego charakterystyki użytkowe. Eksploatacja i Niezawodnosc - Maintenance and Reliability 2002; 2(14): 4-25.

7. Jakubowski R, Orkisz M, Wygonik P. Preliminary Analysis of Two Combustors Turbofan Engine. Journal of KONES Powertrain and Transport 2013; 2(20):175-180.

8. Lefebvre A H. Gas Turbine Combustion 3th ed. Taylor and Francis Group, 2010, http://dx.doi.org/10.1201/9781420086058.

9. Liew K H, Urip E, Yang S L. Parametric Cycle Analysis of a Turbofan with Interstage Turbine Burner. Journal of Propulsion and Power 2015; (3)21: 546-551, http://dx.doi.org/10.2514/1.2546.

10. Liew K H, Urip E, Yang S L, Mattingly J D, Marek C J. Performance Cycle Analysis of a Two-spool Separate-exhaust Turbofan with Interstage Turbine Burner. Journal of Propulsion and Power 2006; 2(22): 411-416, http://dx.doi.org/10.2514/1.13394.

11. Lin T, Lee J, Lwin T. Integrated approach for rotor blade manufacturing cost estimate. Aircraft Engineering and Aerospace Technology 2011; 4(83): 235-244, http://dx.doi.org/10.1108/00022661111138657.

12. Liu F, Sirignano W A. Turbojet and Turbofan Engine Performance Increases Through Turbine Burners. Journal of Propulsion and Power 2001; 3(17): 695-705, http://dx.doi.org/10.2514/2.5797.

13. Majka A. Multiple objective optimization of the power unit for a very light jet. Aircraft Engineering and Aerospace Technology 2014; 3(86): 234-241.

14. Merkisz J, Markowski J, Pielecha J. Emission tests of the F100-PW-229 turbine jet engine during pre-flight verification of the F-16 aircraft. AIR POLLUTION XXI Book Series: WIT Transactions on Ecology and the Environment 2013; 174: 219-230, http://dx.doi.org/10.2495/ AIR130191.

15. Peitsch D. Propelling the future - the meaning of ACARE VISION 2050 for the future development of propulsion systems for aircraft. Combustion engines 2011; 4(147): 3-13.

16. Sieniawski J. Nickel and titanium alloys in aircraft turbine engines. Advances in Manufacturing Science and Technology 2003; 3(27): 23-33.

17. Sirignano W A, Liu F. Performance Increases for Gas-Turbine Engines Through Combustion Inside the Turbine. Journal of Propulsion and Power 1999; 1(15): 111-118, http://dx.doi.org/10.2514/2.5398.

18. Walsh P P, Fletcher P. Gas Turbine Performance 2nd ed. Blackwell Publishing and ASME, 2004, http://dx.doi.org/10.1002/9780470774533.

19. Witek L. Simulation of crack growth in the compressor blade subjected to resonant vibration using hybrid method. Engineering Failure Analysis 2015; 49: 57-66, http://dx.doi.org/10.1016/j.engfailanal.2014.12.004.

20. Witek L, Orkisz M, Wygonik P, Musili D N, Kowalski T. Fracture analysis of a turbine casing. Engineering Failure Analysis 2010; 3(18): 914-923. 
21. Wygonik P. Engine and multitask airplane integration: criteria of engine parameters selection. Aircraft Engineering and Aerospace Technology 2013; 6(85): 460-466, http://dx.doi.org/10.1108/AEAT-12-2012-0249.

22. Wygonik P. Selection criteria of internal parameters of turbofan engine for the type of multi-task aircraft mission. Combustion Engines 2013; 154(3): 483-488.

23. http://web.stanford.edu/ cantwell/AA283_Course_Material/GE90_Engine_Data.pdf

\section{Robert JAKUBOWSKI}

Department of Aircrafts and Aircraft Engines

Rzeszow University of Technology

Al. Powstańców Warszawy 8; 35-959 Rzeszów, Poland

E-mail: robert.jakubowski@prz.edu.pl 